\title{
Etyka korczakowska a duch przedsiębiorczości
}

DOI: $10.47050 / 65591760.96-107$

Wojciech Lasota

Tekst jest próbą wycinkowej rekonstrukcji korczakowskiego rozumienia pojęcia przedsiębiorczości, którego Janusz Korczak ściśle nie zdefiniował. Pokazany jest w nim związek między korczakowskim pojmowaniem przedsiębiorczości a ważnymi dla Korczaka wartościami moralnymi: podmiotowością i etyką pracy. Autor stawia tezę, że instytucje korczakowskie sprzyjały rozwijaniu przedsiębiorczości wśród wychowanków oraz popiera tę tezę przykładami odnoszącymi się do historii Domu Sierot.

\section{Słowa kluczowe:}

przedsiębiorczość

podmiotowość

etyka

etyka pracy

Janusz Korczak

Max Weber 


\section{The Janusz Korczak's ethics and the spirit of entrepreneurship}

DOI: $10.47050 / 65591760.96-107$

Wojciech Lasota

The text is an attempt of the fragmentary reconstruction of the Janusz Korczak's concept of entrepreneurship which Janusz Korczak did not define strictly. It shows the connection between Korczak's understanding of entrepreneurship and the moral values important for him: subjectivity and work ethics. The author puts forward the thesis that the Korczak institutions favoured the development of entrepreneurship among foster children. This thesis is supported by examples referring to the history of the Orphans' Home.

\section{Keywords:}

entrepreneurship

subjectivity

ethics

work ethics

Janusz Korczak

Max Weber 


\section{Wstęp}

W swojej słynnej pracy Etyka protestancka a duch kapitalizmu Max Weber (2011) wskazywał istnienie związku między etycznymi postawami, obecnymi w społeczeństwach protestanckich, a prężnym rozwojem pewnego rodzaju kapitalizmu w tych społeczeństwach. Niniejszy tekst ukazuje podobny związek, choć w dużo mniejszej skali: między etycznymi wskazaniami obecnymi w pismach i praktyce Janusza Korczaka a efektami oddziaływania tych wskazań w obszarze swoiście pojmowanej przedsiębiorczości wśród osób, które ich doświadczyły jako wychowankowie Domu Sierot.

Najważniejsza teza artykułu brzmi: jeśli przyjąć jako zasadniczą wartość etyczną traktowanie ludzi z szacunkiem dla ich podmiotowości (by tak skrótowo na razie oddać podejście Korczaka) i zgodnie z tą wartością postępować oraz wpływać na innych ludzi, to możliwe jest przez to zwiększenie możliwości rozwijania przez nich różnorakich kompetencji przedsiębiorczych.

\section{Między Weberem a Korczakiem}

Wyjaśniając pojęcie "ducha kapitalizmu", Weber odwołuje się do pism i osoby Benjamina Franklina, uosabiających owego ducha. Omawiając główną tezę książki, czyli uzasadnioną religijnie motywację protestantów do zarabiania pieniędzy, pisze: „Na pytanie: d l a c z e g o «z ludzi powinniśmy robić pieniądze», Benjamin Franklin, choć sam niezwiązany z żadnym wyznaniem deista, odpowiada w swym Żywocie własnym biblijnym cytatem, który jak powiada, jego rygorystycznie kalwiński ojciec starał mu się wbić w pamięć w młodości: «Widzisz biegłego w s w o i m z a w o d z i e? Będzie on stał przed obliczem królów». Zarabianie pieniędzy jest - o ile odbywa się $w$ legalny sposób - w ramach nowoczesnego porządku gospodarczego rezultatem i wyrazem zdatności w z a w o d z i e i ta zdatność, co rzuca się w oczy, jest prawdziwą alfą i omegą moralności Franklina, objawiającej się zarówno w cytowanym tu fragmencie, jak i we wszystkich jego pismach bez wyjątku" (Weber 2011, s. 78).

Ogromna ważność „zdatności w zawodzie" jest również "alfą i omegą moralności" Korczaka, z jedną zasadniczą różnicą. Dla Franklina sprawdzianem zdatności są pieniądze. Ma ona charakter ściśle zewnętrzny, a ponieważ relacja zdatności z jej finansowym wymiarem zależy od wielu czynników ekonomicznych, społecznych i kulturowych, jest wystawiana - mówiąc metaforycznie - na swoistą codzienną giełdę, na 
której jednostki notują wzrosty i spadki jej wartości. Dla Korczaka wymiar finansowy łączy się z wykonywanym zawodem, ale nie z jakością "zdatności w zawodzie". Ma ona dla niego charakter wewnętrzny i jednostka ma na nią duży wpływ. Jeśli człowiek jest gotów wciąż doskonalić jakość swojej pracy oraz jakość dokonywanej nad nią refleksji, wówczas wysokie poczucie jego zdatności jest w pełni usprawiedliwione, niezależnie od tego, jaką i jak dobrze płatną pracę wykonuje.

Ilustrują to fragmenty pisanego w getcie warszawskim tekstu Dlaczego zbieram naczynia?, który można uznać za modelowy wyraz tego podejścia. Korczak tłumaczy w nim, dlaczego po posiłkach w Domu Sierot zbiera naczynia, choć nie jest to jego obowiązek: „Kiedy zbieram sam, widzę pęknięte talerze, widzę zgięte łyżki, podrapane miseczki. [...] Czasem zerknę, jak rozdaje się dodatki, albo zobaczę, kto przy kim siedzi - i pomyślę sobie o tym i owym. - Bo kiedy coś robię, to nigdy bezmyślnie [wyróżnienie autora]. Ta praca kelnera jest dla mnie i pożyteczna, i miła, i ciekawa. Ale nie to jest ważne. Ważne jest zgoła coś innego. Coś, o czym wiele razy już mówiłem i pisałem, i z czym walczę od lat trzydziestu, od czasu, jak powstał Dom Sierot - walczę bez nadziei zwycięstwa, bez widocznego skutku, ale walki tej przerwać nie chcę i nie mogę.

O to walczę, aby w Domu Sierot nie było roboty delikatnej czy ordynarnej, mądrej czy głupiej, czystej czy brudnej-roboty dla panieneczek i zwyczajnej hołoty. Nie powinno być w Domu Sierot pracowników wyłącznie fizycznych i wyłącznie umysłowych. Ze zgorszeniem i z niesmakiem patrzą w magistrackim internacie na Dzielnej, że podaję rękę posługaczce, i to nawet wtedy, kiedy myje schody i ma mokre ręce. [...]

Szanuję uczciwych pracowników. Ręce ich są dla mnie czyste i zdanie ich ważę na wagę złota. Praczka i stróż bywali na Krochmalnej nie dlatego, żeby im sprawić przyjemność, ale żeby jako znawcy poradzili i pomogli [...].

Ordynarna inkasentka jest dla mnie chamem i pętakiem. Pan Lejzor jest pięknym człowiekiem, choć grzebie się w nieczystościach rur i kanałów. Panna Nacia, gdyby obierała kartofle, byłaby dla mnie równie godna szacunku jak teraz, kiedy pisze na maszynie" (Korczak 1958, s. 592-593).

\section{Duch przedsiębiorczości}

W zaleceniach Rady Unii Europejskiej z dnia 22 maja 2018 r. w sprawie kompetencji kluczowych w procesie uczenia się przez całe życie widnieje 
następujące określenie kompetencji przedsiębiorczych: „Kompetencje w zakresie przedsiębiorczości to między innymi zdolność wykorzystywania szans i pomysłów oraz przekształcania ich w wartość dla innych osób. [...] Obejmują one zdolność pracy samodzielnej i zespołowej, mobilizowania zasobów (ludzi i przedmiotów) oraz prowadzenia działalności gospodarczej" (Zalecenie Rady Unii Europejskiej 2018, s. 11). Widoczna powyżej wielość kompetencji oraz możliwych sposobów ich zastosowania powoduje, że zasadne wydaje się użycie pojęcia "duch przedsiębiorczości" w znaczeniu pewnej dość nieuchwytnej postawy, która jednak bardzo konkretnie może manifestować się w bardzo różnych sytuacjach.

W podobny sposób ujmował Korczak siłę wpływu, który jego zdaniem kształtuje postawy w rodzinach, pisząc o "terenach wychowawczych": "Terenem wychowawczym nazywam duszę rodziny, która panuje, poszczególni członkowie nie mogą zajmować względem niej stanowiska dowolnego. Ta dusza kierująca zmusza, nie znosi oporu" (Korczak 2012, s. 78).

\section{Podmiotowość w etyce korczakowskiej}

Najbardziej doniosłym ze wskazań etycznych Korczaka jest imperatyw zrównania ważności egzystencji dziecka z życiem dorosłego. Przewija się on przez całą jego twórczość. Już w 1899 r., a więc jako 20-latek, pisze: „Dzieci nie będą dopiero, ale są już ludźmi, tak, ludźmi są, a nie lalkami” (Korczak 1983, s. 31). 40 lat później ujmuje to tak: „Myśl przewodnia: dziecko jest równo nam wartościowym człowiekiem" (Korczak 1939, s. 5).

Najtrafniejszym określeniem tego, czego domagał się uparcie Janusz Korczak, jest uznanie godności, rozumianej jako prawo do posiadania praw oraz korzystania z nich, wynikające wyłącznie $z$ faktu bycia istotą ludzką.

Niepodobna jednak, zdaniem Korczaka, oddzielić bycia człowiekiem od korzystania z tego faktu w działaniu, na rzecz własną i czyjąś. Właśnie dlatego naczelną wartością dla Janusza Korczaka wydaje się podmiotowość istoty ludzkiej ( $w$ tym dziecka, ale nie tylko jego), jakkolwiek on sam nie używał tego pojęcia. Pojęcie podmiotowości w kontekście myśli i praktyki korczakowskiej można rozumieć jako „poczucie i możliwość intencjonalnego, realnego wpływu na siebie i otoczenie" (Lasota 2017, s. 14). Inne Korczakowskie wska- 
zania moralne są właśnie pochodną respektowania przez niego podmiotowości.

\section{Korczakowska przedsiębiorczość}

W rozumieniu przedsiębiorczości według Korczaka wyróżnić można następujące elementy: intencję, proces oraz efekt użytku, który w określonych warunkach robi człowiek (również dziecko) ze swoich sił, zasobów i talentów.

Intencja kieruje poczynaniami. Sam o sobie pisał Korczak w tym kontekście: „pracowałem wtedy tylko, kiedy wierzyłem, że praca przynosi pożytek" (Korczak 2008, s. 221). Ta wiara mniej związana jest z tym, co się robi, a bardziej z tym, jak to się robi, kluczowym pojęciem jest tu zaś „pożytek". Przyglądając się efektom działań, można sprawdzić, na ile intencje działania dla pożytku wcielone zostały w czyn. Obszar owego pożytku jest mniej istotny.

Dla Korczaka praca dla dobra wspólnego była wartością ogromną: „Żyłeś? Ile przeorałeś? Ile wypiekłeś chlebów dla ludzi? Ile zasiałeś? Zasadziłeś drzew? Ile ułożyłeś cegieł pod budowę, zanim odejdziesz? [...] Komu i ile ciepła? Jaka była twoja służba? Jakie nagłówki rozdziałów twej drogi?" (Korczak 1986, s. 299). Jednocześnie jednak niezwykle ważna jest dla niego samowiedza i troska o jakość jednostkowego życia. Pisał w liście do Józefa Arnona: „[...] każdy człowiek i somatycznie, i duchowo jest wszechświatem, i kto by umiejętnie kierował tylko samym sobą, ten też spełniłby swoje zadanie; żyjemy pośpiesznie, niedbale, powierzchownie, partacko" (Korczak 2008, s. 234).

Przedsiębiorczość lokuje się dla Korczaka przede wszystkim w procesie przekuwania intencji na czyn, a czynu na efekt. Jest to przy tym zawsze przedsiębiorczość na dwóch poziomach.

Pierwszy poziom jest związany z odpowiedzią na pytanie, na ile sprawnie zostały wykorzystane zasoby, umiejętności czy sieci społeczne, by realizować działania i doprowadzać je do końca. Czy zaangażowane osoby potrafią myśleć, rozmawiać, negocjować, liczyć, przekonywać, ale też wycofywać się, zmieniać plany i godzić się na kompromisy.

Poziom drugi jest związany z odpowiedzią na pytanie, na ile ta sprawność działania wciąż pozostaje etyczna. Skąd wiadomo, że nadal służy ona czyjemuś pożytkowi? Czy pojawia się wola dostrzeżenia, że efekty naszych działań nie są spójne z początkowymi intencjami? Kiedy uruchamiana jest przedsiębiorczość na tym poziomie, działające w taki 
sposób osoby korzystają z zasobów, umiejętności czy sieci społecznych, by korygować swoje działania zgodnie z ich wartościami etycznymi.

\section{Oddziaływanie etyki korczakowskiej}

Czy można zaryzykować tezę, że dzieci, które doświadczyły oddziaływania instytucji korczakowskich, były wychowywane w duchu przedsiębiorczości? I czy rozumienie tej przedsiębiorczości bliskie jest tego, które znajduje się w przywoływanych już zaleceniach Rady Unii Europejskiej?

Zgodnie z naszą wiedzą o sposobie funkcjonowania Domu Sierot na powyższe pytania należy odpowiedzieć twierdząco. W następnych trzech podrozdziałach znajdują się odwołania do historii Domu Sierot, które wskazują na to, że wychowywane tam dzieci:

$\rightarrow$ miały „zdolność wykorzystywania szans i pomysłów oraz przekształcania ich w wartość dla innych osób" (Zalecenie Rady Unii Europejskiej 2018, s. 11);

$\rightarrow$ były kreatywne, wytrwałe, myślały krytycznie oraz rozwiązywały problemy, podejmowały inicjatywę i miały „zdolności do wspólnego działania służącego planowaniu projektów mających wartość kulturalną, społeczną lub finansową" (tamże);

$\rightarrow$ potrafiły „przekształcać pomysły w działanie w sferze osobistej, społecznej i zawodowej" (tamże), a także rozumiały procesy ich powstawania.

\section{Statystyki Domu Sierot}

W roku 1933, w 25-lecie działalności Towarzystwa „Pomoc dla Sierot”, które zawiadywało Domem Sierot, Korczak liczbowo zobrazował aktywność Domu Sierot od roku 1912. Wszystkich wychowanków było 455, z tego 36 osób było w Domu Sierot krócej niż rok, a o dalszych 38 nie miał informacji. 50 osób emigrowało, najwięcej do USA oraz do Belgii, Francji, Anglii i Palestyny. O pozostałych pisze Korczak: „Bieliźniarek - 3. Biuralistek - 8. Ekspedientek (w sklepach -15). Freblanek - 5. Fryzjerek - 3. Gorseciarek - 5. [...] W szkołach - 9. Wychowawczyń w instytucjach społecznych - 4. Biuralistów - 12. Drukarzy - 4. Ekspedientów - 11. Elektrotechników - 3. Fryzjerów - 9. Gońców - 10. [...] Pozostali różnie: czapnik, dorożkarz, fotograf, malarz, muzyk, optyk, rymarz, rzeźnik, tapicer, technik budowlany. Grzebienie, galanteria, manikiurzystka, nauczyciel tańca" (Korczak 2008a, s. 144). 
W sumie minimum 133 zatrudnione lub uczące się kobiety i 108 mężczyzn, łącznie ponad 241 osób. Oznacza to, że zdecydowanie ponad połowa wychowanków i wychowanek Domu Sierot była w stanie wykształcić się w zawodzie, a następnie znaleźć i utrzymać zatrudnienie na trudnym, pokryzysowym rynku pracy. Korczak do tego zestawienia dopisał jeszcze: „Chwila wahania - wreszcie na 455 - 2 żebraków, 2 prostytutki, 3 za kradzieże sądzeni. Ten zrozumie, kto przeżył” (tamże, s. 144). Oznacza to, że tylko siedem na ponad 450 osób, które w ciągu 25 lat były wychowywane w Domu Sierot, znalazło się w konflikcie z prawem.

\section{List z Argentyny}

Został on opublikowany w sprawozdaniu Towarzystwa "Pomoc dla Sierot" za 1931 r. Autorem jest były wychowanek Domu Sierot o nieznanym nam imieniu i nazwisku, który przymiera głodem w Argentynie, szukając pracy. W 1931 r. niespodziewanie spotyka tam innego wychowanka, Dawida: „W pierwszych dniach po naszym spotkaniu żyliśmy w wielkiej zgodzie, ale potem zaczęły się ujawniać wady jego i moje, a więc - kłótnie. Zaczęliśmy się zastanawiać, co robić, by zaprzestać się kłócić. Oto cośmy uradzili:

1. Najważniejszym bodźcem kłótni jest zły humor jednego z nas. Kiedy więc jeden jest w złym humorze, a nie chce $z$ drugim rozmawiać, mówi: «Nie mów teraz do mnie» i ten «drugi» jest obowiązany nie mówić do «pierwszego» przez godzinę.

2. Kłótnie następowały także w razach, gdy miano coś uradzić, a żaden nie chciał ustąpić, wtedy mieliśmy urządzić losowanie.

3. Są spory, których nie można przeprowadzić przez losowanie, gdyż są za bardzo ważne dla naszego pobytu [...]. Wtedy się tę sprawę odkłada na kilka minut, a potem jeden mówi, dlaczego chce czy nie chce, i drugi robi to samo. Oczywiście «przemówienia stron» nie są przerywane.

Z umowy naszej skorzystaliśmy" (Korczak 2008a, s. 130).

To jeden z najdobitniejszych dowodów oddziaływania siły korczakowskich instytucji. Obaj chłopcy zyskali tam świadomą kompetencję w zakresie radzenia sobie z trudnościami. Zastosowali ją w sytuacji, w której bez odpowiednich umiejętności łatwo byłoby się dać ponieść emocjom, tendencji do wzajemnego obwiniania się czy innym destrukcyjnym impulsom. Również następne strony listu poświęcone 
są opisowi działań ściśle przedsiębiorczych, takich jak perypetie związane z szukaniem pracy, która pozwoliłaby chłopcom zarobić na noclegi i jedzenie. Najpierw pracę znalazł Dawid, potem autor listu, który w jego zakończeniu pisze następująco: „Wyjazdu mego do Argentyny absolutnie nie żałuję. Nauka życia wiele znaczy; więcej jak pieniądz i dobry byt" (tamże, s. 138).

\section{Z Warszawy do Ottawy}

Przykładem proprzedsiębiorczej siły oddziaływania Domu Sierot, który jest najbliższy potocznemu rozumieniu pojęcia przedsiębiorczości, a zarazem "duchowi kapitalizmu" w aspekcie zarabiania pieniędzy, są losy Leona Gluzmana, opisane w książce Oby im życie łatwiejsze było (Medvedeva-Nathoo 2012).

Leon Gluzman, urodzony około 1914 r., trafił do Domu Sierot po śmierci ojca w roku 1923 i opuścił go siedem lat później, kiedy wyjechał do Kanady, co było możliwe wyłącznie dzięki temu, że mieszkał tam jego wuj. Borykając się w Ottawie z wielkim kryzysem, korzystał właśnie z umiejętności i ze swoistego treningu, jaki przeszedł w Domu Sierot: „Leon, sierota, biedny jak mysz kościelna, był samoukiem, w biegu opanowywał zawód księgowego (umiejętność szybkiego uczenia się wyniósł z Domu Sierot, gdzie priorytetem było sprawne opanowanie czytania i pisania), a po otrzymaniu wymarzonego Commerce diploma [...] w 1946 roku założył własny biznes - najpierw była to skromna firma księgowa. Z czasem się rozrosła. Dziś należy do dwudziestu największych tego typu firm w Kanadzie" (Medvedeva-Nathoo 2012, s. 61-62).

Firma ta nosi nazwę GGFL Chartered Professional Accountants. GGFL od nazwisk założycieli: Ginsberg, Gluzman, Fage i Levitz.

Uznając tezę o kształtowaniu wśród dzieci w Domu Sierot postaw przedsiębiorczych za uzasadnioną, konieczne jest poczynienie pewnego zastrzeżenia. Z pewnością nie wszystkie dzieci mające kontakt z instytucjami korczakowskimi nabywały umiejętności przedsiębiorczych. Biorąc jednak pod uwagę, że Korczak pracował z dziećmi o ogromnych deficytach w wielu obszarach, wykazywanie kompetencji przedsiębiorczych u chociażby części z nich świadczy o tym, że w jego instytucjach panował klimat niezwykle sprzyjający rozwojowi tych kompetencji.

1. Na stronie internetowej firmy (www.ggfl.ca/why-ggfl) można zobaczyć zdjęcia założycieli oraz film nakręcony z okazji jubileuszu firmy. 


\section{Czy przedsiębiorczość po korczakowsku to nierealna wizja?}

Uściślając powyższe pytanie: Czy we współczesnym świecie sprawność przedsiębiorczego działania powinna być w zgodzie z wartościami etycznymi, w imię których działania te są podejmowane?

Mogłoby się wydawać, że to idealistyczne mrzonki. Jednakże już w 1954 r. jeden z niekwestionowanych autorytetów w dziedzinie zarządzania, Peter Drucker, pisał, że odpowiedzialności menedżerów nie można dłużej „opierać na założeniu, że osobisty interes właściciela będzie go wiódł ku dobru ogólnemu lub że interes osobisty i dobro ogółu można oddzielić, traktując jako kategorie niemające ze sobą nic wspólnego. Wręcz przeciwnie, odpowiedzialność ta wymaga dzisiaj od menedżera, by przyjął odpowiedzialność za dobro ogółu, by podporządkował swe działania normom etycznym, ograniczając swój własny interes i władzę $w$ razie, gdyby ich egzekwowanie godziło $w$ dobro powszechne i wolność jednostki" (Drucker 1998, s. 408).

Stanowisko Druckera, bardzo bliskie poglądom Korczaka, znajduje dziś godnych kontynuatorów, żeby wymienić jedynie Tomáša Sedláčka (zob. Sedláček 2011), ruch Humanistic Management (zob. Humanistic Management Center) czy polską koncepcję Open Eyes Economy (zob. Open Eyes Economy) i projekt "Nie nieodpowiedzialności" (zob. Nienieodpowiedzialni).

Powyższe rozważania potwierdzają tezę postawioną na początku artykułu: jeśli przyjąć za zasadniczą wartość etyczną traktowanie ludzi z szacunkiem dla ich podmiotowości i zgodnie z tą wartością postępować $z$ innymi ludźmi i na nich wpływać, to możliwe jest przez to zwiększenie możliwości rozwijania przez nich różnorakich kompetencji przedsiębiorczych.

Janusz Korczak przez dziesięciolecia prowadził instytucje, w których ludzie traktowani byli z szacunkiem dla swojej podmiotowości. Zwiększenie ich kompetencji przedsiębiorczych nie było tu samoistnym celem, ale środkiem do celu znacznie ważniejszego: umiejętności samodzielnego kształtowania przez dzieci ich życia w poczuciu własnej podmiotowości. Losy wielu wychowanek i wychowanków Korczaka pokazują, że posiedli tę umiejętność, w tym także kompetencje przedsiębiorcze. Dlatego również dziś możemy i powinniśmy w tym zakresie czerpać z bogatego dziedzictwa Janusza Korczaka. 


\section{Bibliografia}

$\rightarrow$ Drucker, P. (1998), Praktyka zarzq̨dzania, tłum. J.W. Gołębiowski, Kraków: Wydawnictwo Czytelnik, Nowoczesność, Akademia Ekonomiczna w Krakowie.

$\rightarrow$ Korczak, J. (1958), Pamiętnik [w:] Wybór pism, Warszawa: Nasza Księgarnia.

$\rightarrow$ Korczak, J. (1983), Rozwój idei miłości bliźniego w XIX wieku [w:] M. Falkowska (red.), Myśl pedagogiczna Janusza Korczaka. Nowe źródła, Warszawa: Nasza Księgarnia.

$\rightarrow$ Korczak, J. (1986), Samotność starości [w:] Pisma wybrane, t. IV, Warszawa: Nasza Księgarnia.

$\rightarrow$ Korczak, J. (2008a), Zamiast wstępu [do sprawozdania za okres 1930/31] [w:] Dzieła, t. 14/1, Warszawa: Instytut Badań Literackich.

$\rightarrow$ Korczak, J. (2008a), Losy byłych wychowańców Domu Sierot od roku 1912 do roku 1932 (Od otwarcia Domu Sierot [w:] Dzieła, t. 14/1, Warszawa: Instytut Badań Literackich.

$\rightarrow$ Korczak, J. (2008b), Do przyjaciół w Ein Harod [list z 23.05.1937 r.] [w:] Dzieła, t. 14/2, Warszawa: Instytut Badań Literackich.

$\rightarrow$ Korczak, J. (2008b), Do Józefa Arnona [list z 3.07.1938 r.] [w:] Dzieła, t. 14/2, Warszawa: Instytut Badań Literackich.

$\rightarrow$ Weber, M. (2011), Etyka protestancka i duch kapitalizmu, tłum. D. Lachowska, Warszawa: Wydawnictwa Uniwersytetu Warszawskiego.

$\rightarrow$ Sedláček, T. (2011), Ekonomia dobra i zła, tłum. D. Bakalarz, Warszawa: Studio Emka. 


\section{Netografia}

$\rightarrow$ Humanistic Management Center, www.humanisticmanagement.org (dostęp 20.11.2018).

$\rightarrow$ Korczak, J. (1939), Pedagogika żartobliwa, Warszawa: Wydawnictwo J. Mortkowicza, www.dbc.wroc.pl/Content/13804/RP1342_Pedagogika_zartobliwa. pdf (dostęp: 20.11.2018).

$\rightarrow$ Korczak, J. (2012), Jak kochać dziecko. Dziecko w rodzinie, Warszawa: Biuro Rzecznika Praw Dziecka. Por. również rozważania na ten temat na kolejnych stronach, s. 79-83, brpd.gov.pl/sites/default/files/jak_kochac_dziecko_dziecko_w_rodzinie.pdf (dostęp: 20.11.2018).

$\rightarrow$ Lasota, W. (2017), Janusz Korczak w starej i nowej Europie [w:] Janusz Korczak w starej i nowej Europie, Warszawa: Fundacja Korczakowska, issuu.com/korczakowska/docs/janusz_korczak_w_starej_i_nowej_eur (dostęp: 20.11.2018).

$\rightarrow$ Medvedeva-Nathoo, O. (2012), Oby im życie łatwiejsze było, Poznań: Uniwersytet im. Adama Mickiewicza, www.januszkorczak.ca/wp-content/ uploads/2016/12/Janusz-Korczak_2012.pdf (dostęp: 27.11.2018).

$\rightarrow$ Nienieodpowiedzialni, nienieodpowiedzialni.pl (dostęp: 20.11.2018).

$\rightarrow$ Open Eyes Economy, oees.pl (dostęp: 20.11.2018).

$\rightarrow$ Zalecenie Rady z dnia 22 maja 2018 r. w sprawie kompetencji kluczowych w procesie uczenia się przez całe życie, eur-lex.europa.eu/legal-content/PL/TXT/ PDF/?uri=CELEX:32018H0604(01)\&from=en (dostęp: 27.11.2018). 